\title{
Penegakan Hukum Terhadap Pelanggaran Protokol Kesehatan yang Dilakukan Masyarakat Pada Masa Pandemi Covid-19 di Kota Ambon
}

\author{
Sherly Adam ${ }^{1 *}$, Reimon Supusepa ${ }^{2}$, Jacob Hattu ${ }^{3}$, Iqbal Taufik 4 \\ 1, 2, 3, ${ }^{4}$ Fakultas Hukum Universitas Pattimura, Ambon, Indonesia \\ *E-mail:sherly74adam@gmail.com
}

Dikirim: 08/12/2021

\begin{tabular}{l}
\hline Info Artikel \\
Keywords: \\
Law Enforcment; \\
health protocol \\
violators; Covid-19.
\end{tabular}

Kata Kunci:

Penegakan hukum; pelanggar protokol kesehatan; Covid-19.

\section{Abstract}

This study aims: 1. To determine and analyze law enforcement against violations of health protocols during the Covid-19 pandemic in Ambon City. 2. To find out and analyze the application of sanctions for violations of health protocols committed by the community during the Covid-19 pandemic in Ambon City. This research was conducted using a normative juridical research using a statutory approach, a conceptual analysis approach which is a descriptive study of qualitative analysis. The results of this study indicate that Law Enforcement against violations of health protocols during the Covid 19 pandemic in Ambon City is carried out based on statutory regulations, by limiting Community Activities (PKM), Large-Scale Social Restrictions (PSBB) as a form of law enforcement against health protocol violations. during the Covid 19 pandemic in Ambon City through socialization in preventing the spread of the Covid 19 virus and Large-Scale Social Restrictions (PSBB) by applying sanctions against offenders. However, law enforcement against violations of health protocols has not been carried out properly. This is due to the fact that health protocol violations are still occurring in Ambon city. 2. Imposing sanctions for violations of health protocols during the COVID-19 pandemic in Ambon city which is regulated in the Ambon City Mayor's Regulation on PSBB by applying written warning sanctions, administrative sanctions, social sanctions and criminal sanctions to violators. However, the application of sanctions against violators has not provided a deterrent effect on health protocol violators.

Abstrak
Penelitian ini bertujuan: 1. Untuk mengetahui dan menganalisis penegakan
hukum terhadap pelanggaran protokol kesehatan pada masa pandemi
covid-19 di Kota Ambon. 2 . Untuk mengetahui dan menganalisis penerapan
sanksi terhadap pelanggaran protokol kesehatan yang dilakukan mayarakat
pada masa pandemi covid-19 di Kota Ambon. Penelitian ini dilakukan
dengan menggunakan jenis penelitian yuridis normatif dengan
menggunakan pendekatan perundang-undangan, pendekatan analisa
konsep yang bersifat kajian deskriptif analisis kualitatif. Hasil penelitian ini
menunjukan bahwa Penegakan Hukum Terhadap pelanggaran protokol
kesehatan pada masa pandemi covid-19 di kota Ambon dilaksanakan
berdasarkan peraturan perundang-undangan, dengan melakukan
Pembatasan Kegiatan Masyarakat (PKM), Pembatasan Sosial Berskala


DOI:

10.47268/sasi.v27i2.441

Besar (PSBB) sebagai bentuk penegakan hukum terhadap pelanggaran protokol kesehatan pada masa pandemi covid-19 di Kota Ambon melalui sosialisasi-sosialisasi dalam pencegahan penyebaran virus covid 19 dan Pembatasan Sosial Berskala Besar (PSBB) dengan menerapkan sanksi terhadap pelanggar. Namun penegakan hukum terhadap pelanggaran protokol kesehatan belum terlaksana dengan baik. Hal ini disebabkan masih terjadinya pelanggaran-pelanggaran protokol kesehatan yang dilakukan oleh masyarakat di kota Ambon. 2. Penerapan sanksi terhadap pelanggaran protokol kesehatan pada masa pandemi covid 19 di kota Ambon yang diatur dalam Peraturan Wali Kota Ambon tentang PSBB dengan menerapkan sanksi teguran tertulis, sanksi administrasi, sanksi sosial dan sanksi pidana kepada pelanggar. Namun penerapan sanksi terhadap pelanggar belum memberikan efek jera kepada pelanggar protokol kesehatan.

\section{A. PENDAHULUAN}

Hukum merupakan himpunan petunjuk hidup, yang mengatur tata tertib dalam suatu masyarakat. Pergaulan hidup sebagai masyarakat yang teratur adalah sesuatu dari hukum yang terlihat dari luar, akan tetapi hukum juga dikelompokan dalam suatu sistem yang disusun secara sengaja dan seharusnya ditaati oleh anggota masyarakat yang bersangkutan ${ }^{1}$. Sehingga, kebebasan individu sebagai kekuatan pengerak utama dari proses penyesuaian sosial, dan kebijakan pidana dan hukum pidana yang modern memberikan arti agar setiap perlakuan readaptasi sosial, harus diarahkan pada perbaikan terhadap penguasaan diri sendiri ${ }^{2}$.

Akhir-akhir ini banyak dipermasalahkan tentang merosotnya kesadaran hukum. Pandangan tentang merosotnya kesadaran hukum disebabkan karena terjadinya pelanggaranpelanggaran hukum dan ketidakpatuhan hukum. Bahkan yang lebih menyedihkan ialah bahwa tidak sedikit orang yang menjadi panutan, orang yang tahu hukum justru ia yang melanggar hukum. Bahkan meningkatnya kriminalitas bukan hanya dalam kuantitas dan volumenya saja, tetapi juga dalam kualitas atau intensitas serta jenisnya.

Hukum haruslah sesuai dengan kesadaran hukum masyarakat, artinya hukum harus mengikuti kehendak dari masyarakat. Hukum yang baik adalah hukum yang sesuai dengan perasaan hukum manusia (perorangan). Maksudnya sama, hanya jika kesadaran hukum dikaitkan dengan masyarakat, sementara perasaan hukum dikaitkan dengan manusia perorangan, sehingga dapatlah disebutkan bahwa kesadaran hukum sebenarnya merupakan generalisasi dari perasaan hukum ${ }^{3}$.

Upaya pencegahan dan pemutusan rantai penyebaran COVID-19 di Indonesia membutuhkan kedisiplinan pada banyak aspek, terutama kehidupan sosial masyarakat. Dalam situasi pandemi, diperlukan disiplin yang sangat ketat terhadap kehidupan sosial masyarakat dalam bentuk physical distancing. Metode ini dianggap sebagai upaya yang paling efektif untuk mencegah dan mengurangi angka penyebaran virus ini.

Pemerintah memperkuat kewajiban physical distancing melalui Peraturan Pemerintah Nomor 21 Tahun 2020 tentang Pembatasan Sosial Berskala Besar (PSBB) dan Peraturan Kementerian Kesehatan (Permenkes) No. 9 Tahun 2020. Aturan ini harus dipatuhi dan untuk memastikan kepatuhan tersebut, Polri menjadi garda terdepan. Dalam konteks inilah, selain tenaga medis, Polri dapat disebut sebagai garda terdepan dalam upaya pencegahan penyebaran

1 Apeldoorn, L. V., \& Van, L. J. (2009). Pengantar Ilmu Hukum, terjemahan Oetarid Sadino. Jakarta: Pradnya Paramitha, h. .6.

2 Arief, B. N. (1997). Beberapa aspek kebijakan penegakan dan pengembangan hukum pidana. Bandung: Citra Aditya Bakti, h. 43.

3 Fuady, M. (2007). Sosiologi Hukum Kontemporer, Interaksi Kekeuasaan, Hukum, dan Masyarakat, Bandung: Citra Aditya Bakti, h. 75.

$$
\text { 231|SASI Vo1.2 } 7 \text { No.2, April - Juni } 2021
$$


COVID-19. Keberhasilan PSBB memang tergantung dari kesadaran dan kedisiplinan masyarakat, namun untuk memastikan keduanya berjalan, diperlukan peran Polri di dalamnya ${ }^{4}$. Pemerintah telah membuat aturan dan kebijakan yang memadai serta peraturan pelaksanaan di semua kementerian sehingga menjadi acuan bagi pemerintah di daerah untuk menghadapi Pandemi Covid-19. Dalam penegakan hukum, pidana menjadi pilihan terakhir untuk dijadikan sanksi bagi masyarakat yang melanggar ${ }^{5}$.

Penegakan hukum bertujuan untuk mencapai tujuan hukum. Melalui penegakan hukum, diharapkan tujuan hukum dapat tercapai sehingga hukum dapat berfungsi sebagaimana mestinya ${ }^{6}$. Penegakan hukum adalah proses dilakukannya upaya untuk tegaknya atau berfungsinya norma-norma hukum secara nyata sebagai pedoman perilaku dalam lalu-lintas atau hubungan-hubungan hukum dalam kehidupan bermasyarakat dan bernegara ${ }^{7}$.

Berdasarkan data Gugus Tugas Percepatan Penanganan Covid-19, jumlah kumulatif kasus positif Covid-19 sampai Jumat (17/7) mencapai 83.130. Dengan jumlah sebanyak itu, Indonesia menempati peringkat 26 dunia berdasarkan data Worldometers. Peringkat 25 ditempati Tiongkok dengan jumlah kumulatif $83.622^{8}$, dengan penambahan 1.000 kasus per hari di Indonesia, sedangkan Tiongkok--negara pertama yang melaporkan kasus Covid-19-hanya bertambah kurang dari 100 kasus sehari, dapat dipastikan peringkat Indonesia berada di atas Tiongkok. Jumlah tersebut akan bertambah signifikan hingga di atas 100.000, bahkan 200.000 kasus, apabila puncak Covid-19 di Indonesia terjadi pada Agustus atau September 2020.

Tak heran apabila Presiden Joko Widodo (Jokowi) beberapa kali menyoroti ketidakdisiplinan masyarakat dalam menjalankan protokol kesehatan. Awal pekan ini di Istana Merdeka Jakarta, Jokowi menyatakan pemerintah akan memberlakukan sanksi bagi pelanggar protokol kesehatan. Jokowi mengutip hasil survei di salah satu provinsi yang menunjukkan sekitar 30\% warga yang tak mematuhi protokol kesehatan. Bahkan, 70\% warga tidak menggunakan masker.

Kasus positif Covid-19 yang terus meningkat di Indonesia khususnya di Maluku. Awal mula dari penemuan seorang pasien yang positif terinfeksi virus corono pada tanggal 22 Maret 2020 maka pemerintah Provinsi Maluku melakukan tanggap darurat selama 14 hari. Tim Gugus Tugas Percepatan Penanganan Corona Virus Disease 2019 (COVID-19) Maluku telah melakukan langkah-langkah pencegahan dengan melakukan pelacakan jejak pasien positif Corona. Namuntak lepas dari perilaku masyarakat yang belum atau tidak disiplin melaksanakan protokol kesehatan, Provinsi Maluku khususnya koata Ambon memmbuat penyebaran virus corona semakin meningkat.

Sejauh ini memang para pelanggar protokol kesehatan telah menerima sanksi, yakni sanksi sosial dan denda. Namun, sanksi tersebut belum memberikan efek jera secara signifikan. Oleh karena itu, pemerintah mendorong agar sanksi bagi pelanggar protokol kesehatan diperberat dengan memperbesar nilai denda atau menjalani hukuman kurungan paling lama tiga bulan karena melakukan tindak pidana ringan (tipiring). Setidaknya ada tiga lokasi yang menjadi sasaran utama penerapan protokol kesehatan, yakni pasar, angkutan

${ }^{4}$ Siregar, S. N. Polisi Di Masa Pandemi Covid-19:Kompleksitas Masalah Penegakan Hukum dan Pilihan Solusi, Pusat Penelitian Politik, http://www.politik.lipi.go.id/kolom/kolom-2/politik-nasional/1391-polri-di-masapandemi-covid-19-kompleksitas-masalah-penegakan-hukum-dan-pilihan-solusi, (Diakses tanggal 9 November 2020).

5 Very, Protokol Kesehatan Dibuat untuk Kesehatan dan Keselamatan Masyarakat dari Wabah Covid-19, Indonews.id, https://indonews.id/artikel/29311/Protokol-Kesehatan-Dibuat-untuk-Kesehatan-dan-KeselamatanMasyarakat-dari-Wabah-Covid-19/, (Diakses tanggal 9 November 2020).

6 Arief, B. N. Op. Cit., h. 15.

7 Sunarso, S. (2005). Wawasan Penegakan Hukum di Indonesia. Bandung: Citra Aditya Bakti, h. 10.

8 Berita Satu Suara Pembaharuan, Tajuk Rencana, Penegakan Protokol Kesehatan, https://beritasatumedia.cld.bz/SP-200718/6/, (Diakses tanggal 9 November 2020). 
umum, dan ruang terbuka publik. Hingga saat ini, pasar menjadi salah satu klaster penyebaran Covid-19. Setelah menjalani swab test, para pedagang di berbagai pasar tradisional di Indonesia diketahui tertular Covid-19 ${ }^{9}$. Ketidakpatuhan dan ketaatan masyarakat terhadap protocol kesehatan yang menyebabkan penyebaran virus corona ini semakin meningkat khususnya di kota Ambon sehingga diperlukan penegakan hukum terhadap pelanggaran-pelanggaran yang dilakukan masyarat pada masa pandemi covid 19 di Kota Ambon.

\section{B. METODE PENELITIAN}

Penelitian ini merupakan penelitian normatif. Pendekatan masalah yang digunakan dalam pentian ini adalah menggunakan pendekatan perundang-undangan (statute approach), dan pendekatan konsep (conceptual approach), untuk mendapatkan data yang akurat, maka penelitian ini menggunakan data Primer dan data sekunder. Data danbahan hukum yang diperoleh melalui penelitian ini selanjutnya diindentifikasi dan dikumpulkan berdasarkan permasalahan yang dirumuskan dan diklasifikasikan menurut sumber dan susunan tingkatannya secara utuh dan komprehensif untuk dianalisis dan dibahas. Tahap pengumpulan bahan hukum dilakukan melalui studi kepustakaan, pengambilan data dan wawancara pada Kantor Walikota Ambon, Dinas Perhubungan Kota Ambon, Kepolisian Daerah Maluku, danKepolisianResor Kota Ambon. Bahan hokum dan data tersebut kemudian dianalisis secara kualitatif.

\section{PEMBAHASAN}

\section{Penegakan Hukum Terhadap Pelanggaran Protokol Kesehatan Di Masa Pandemi Covid 19 Di Kota Ambon}

Akhir tahun 2019 menjadi waktu yang tidak pernah di duga sebelumnya, muncul sebuah ancaman bagi kesehatan masyarakat dimana pertama kali wabah ini ditemukan di Wuhan dan diberinama Corona Virus Disease 2019, tidak butuh waktu lama kemudian berkembang pandemi ke seluruh belahan dunia sehingga Badan Kesehatan Dunia (WHO) menetapkan Covid-19 sebagai pandemi pada tanggal 11 Maret 2020. Secara resmi di Indonesia Presiden Joko Widodo menetapkan covid-19 menjadi bencana nasional non alam pada tanggal 13 April 2020 melalui Keputusan Presiden No. 12 tahun 2020 Tentang Penetapan Bencana Non Alam Penyebaran Corona Virus Disease 2019 (COVID-19) Sebagai Bencana Nasional ${ }^{10}$.

Dimaknai sebagai pandemi perkembangan virus ini sesuai dengan kondisi di lapangan saat ini, di mana virus corona telah melanda sebagian orang diberbagai macam daerah dibelahan dunia dengan demikian pesat. Makna kata pandemi sendiri berasal dari kata bahasa Yunani"pan", yang berarti seluruh, serta"demo", yang berarti orang. Istilah pandemi diberlakukan dan dilegalkan sebab penularannya yang begitu pesat. Sebutan ini tak mengacu pada kecakapan dan kemampuan maupun meningkatnya korban wafat, akan tetapi masa perkembangan serta penyebarannya. Kendati demikian, bukan berarti virus corona selalu berujung pada kematian status pandemi merupakan wabah sebuah penyakit virus corona yang sudah menggapai titik spot kritis, karena menyebar ke sebagian negeri dengan begitu pesat disertai tewasnya ribuan orang ${ }^{11}$.

Salah satu terdampak pandemi Covid-19, yang hingga saat tulisan ini dikerjakan masih

9 Ibid

10 Saragih, N. I., Hartati, V., \& Fauzi, M. (2020). Tren, Tantangan, dan Perspektif dalam Sistem Logistik pada Masa dan Pasca (New Normal) Pandemik Covid-19 di Indonesia. Jurnal Rekayasa Sistem Industri, 9(2), 7786. DOI: https://doi.org/10.26593/jrsi.v9i2.4009.77-86

11 Masrul, M., Tasnim, J. S., Daud Oris Krianto Sulaiman, C. P., Purnomo, A., Febrianty, D. H. S., Purba, D. W., \& Ramadhani, Y. R. (2020). Pandemik COVID-19: Persoalan dan Refleksi di Indonesia. Medan: Yayasan Kita Menulis, h. 45.

$$
\text { 233|SASI Vo1. } 27 \text { No.2, April - Juni } 2021
$$


terus mengalami pelonjakan jumlah pasien Covid-19 dari seluruh wilayah di Indonesia. Pemerintah sebagai pemangku kebijakan telah menjadikan Covid-19 sebagai bencana nasional non-alam. Lonjakan kasus yang sangat cepat semakin memicu kekhawatiran masyarakat, semakin tinggi jumlah kasus tersebut membuat pemerintah segera mengambil langkah membuat kebijakan antisipatif untuk mengatasi virus corona di Indonesia. Presiden Republik Indonesia dan Pemerintah Daerah serta lembaga terkait secara bersama-sama membuat kebijakan sebagai sebuah langkah taktis dalam upaya pencegaham covid-19. Mulai dari pemerintah pusat, menteri sampai kepala daerah provinsi, kabupaten bahkan pemerintah kota ${ }^{12}$.

Tidak terlepas dari dampak penyebaran viris corona yang sangat cepat di luar negeri maupun dalam negeri memberikan perubahan pada seluruh bidang kehidupan salah satunya ekonomi. Prediksi Bank Dunia perkembangan ekonomi Indonesia akan tertekan sebesar 2,1 persen. Proyeksi pertumbuhan ekonomi yang diramalkan oleh Bank Indonesia yang biasanya mencapai di atas 5\% kini hanya sekitar 2,5\%. ${ }^{13}$

Sebagai upaya agar penanganan covid-19 menjadi cepat pemerintah juga melalui Peraturan Menteri Kesehatan No 9 tahun 2020 tentang pedoman Pembatasan Sosial Berskala Besar (PSBB) sebagai bentuk terusan dari Peraturan Pemerintah No 21 tahun 2020 tentang PSBB. Dengan dilaksankannya PSBB seluruh kegiatan perkantoran dirumahkan. Hal ini dilakukan pemerintah sebagai sebuah strategi untuk memutus rantai penyebaran ke wilayah tertentu tentunya dengan lebih dulu melihat dan ekonomi sebagai pertimbangan utama. Kebijakan ini tentunya tidak akan berhasil apabila tidak ada kontribusi dari masyarakat, sehingga dibutuhkan kesadaran masyrakat untuk mentaati peraturan agar penyebaran covid-19 bisa diputus dan melindungi orang-orang dari tertularnya virus ini. ${ }^{14}$ Upaya ini dilakukan tentunya untuk mencegah dan menangkal keluar masuknya virus dari satu wilayah ke wilayah yang lainnya. ${ }^{15}$

Kota Ambon merupakan salah kota di Indonesia yang mempunyai dampak secara ekonomi, sosial, budaya dan agama dengan adanya penyebaran virus covid-19. Berdasarkan arahan dari Pemerintah Pusat, langkah awal dilakukan Pemerintah Kota dengan memproteksi pintu-pintu masuk dari luar khususnya di Kota Ambon. Setiap orang yang masuk ke Maluku jika memiliki KTP Maluku maka diinstruksikan untuk melakukan karantina mandiri dan jika KTP dari luar Maluku maka Pemda menyiapkan tempat untuk di karantina. Di Kota Ambon, Pemerintah juga telah menyiapkan empat Rumah Sakit Rujukan Covid-19 di Kota Ambon, dengan ketersediaan Alat Pelindung Diri yang memadai.

Kemudian untuk tenaga kesehatan yang bertugas, telah disiapkan tiga hotel sebagai tempat tinggal mereka sementara. Jadi selama dua minggu mereka tidak pulang ke rumah, nanti setelah 14 hari baru mereka bisa pulang ke rumah selama dua-tiga hari, baru balik kembali bekerja. Upaya konkrit yang dilakukan di Kota Ambon adalah telah melakukan rapid tes massal. Hanya saja pemerintah kesulitan untuk melakukan pemeriksaan swab sehingga sebagian harus dikirimkan untuk diuji Laboratorium di Jakarta.

12 Zahrotunnimah, Z. (2020). Langkah taktis pemerintah daerah dalam pencegahan penyebaran virus Corona Covid-19 di Indonesia. SALAM: Jurnal Sosial Dan Budaya Syar-I, 7(3), $247-260$. DOI: https://doi.org/10.15408/sjsbs.v7i3.15103.

13 Juaningsih, I. N., Consuello, Y., Tarmidzi, A., \& NurIrfan, D. (2020). Optimalisasi Kebijakan Pemerintah dalam penanganan Covid-19 terhadap Masyarakat Indonesia. SALAM: Jurnal Sosial dan Budaya Syar-i, 7(6), 509518. DOI: https://doi.org/10.15408/sjsbs.v7i6.15363

14 Nasruddin, R., \& Haq, I. (2020). Pembatasan sosial berskala besar (PSBB) dan masyarakat berpenghasilan rendah. SALAM: Jurnal Sosial dan Budaya Syar-i,7(7), 639-648. DOI: https://doi.org/10.15408/sjsbs.v7i7.15569.

${ }_{15}$ Made, I. L. (2020). Signifikansi Pengaruh Sentimen Pemberlakuan PSBB Terhadap Aspek Ekonomi: Pengaruh Pada Nilai Tukar Rupiah dan Stock Return (Studi Kasus Pandemi Covid-19). Jurnal Bina Akuntansi, 7(2), 223-239. DOI: https://doi.org/10.52859/jba.v7i2.98. 
Langkah Pemerintah Kota Ambon dalam mengantisipasi Covid-19 yaitu dengan cara melakukan upaya pencegahan melalui sosialisasi kepada guru-guru, siswa-siswa, komunitaskomunitas, tokoh Masyarakat, dan tokoh Agama. Pemerintah Kota Ambon juga menyediakan tempat pencuci tangan di tempat umum, meminta seluruh penjahit di Kota Ambon untuk menjahit masker, kemudian kita beli dan bagikan kepada masyarakat. Selain itu adanya pembatasan jumlah penumpang di dalam mobil, membuat pos Covid-19 pada titik-titik masuk dari luar Kota Ambon ke dalam Kota Ambon, memberikan bantuan-bantuan sosial kepada masyarakat, dan memberikan bantuan intensif kepada tenaga kesehatan yang telah berjuang melawan Covid 19 ini.

Ada dua rujukan Undang-Undang yang digunakan negara/pemerintah untuk mengatasi persoalan COVID-19, instrumen hukum di bidang kesehatan yaitu Undang-Undang No. 6 Tahun 2018 tentang Kekarantinaan Kesehatan dan instrumen hukum bidang penanggulangan bencana yaitu Undang-Undang No. 24 Tahun 2007 Tentang Penanggulangan Bencana. Bidang kesehatan turunannya dalam bentuk PSBB, bidang bencana turunannya dalam bentuk Gugus Tugas.

Peraturan Gubernur Nomor 5 Tahun 2020 adalah Pembatasan Sosial Berskal Besar (selanjutnya disingkat PSBB) di Maluku. Namun instrumen hukum tersebut hanya bersifat himbauan. Dalam Peraturan Gubernur tersebut masalahnya terkait dengan 'penindakan atas perbuatan pelanggaran ' bagi mereka yang melanggar dan juga tidak mengatur secara teknis tentang sanksi administratif, subjeknya Badan Hukum atau Orang. Kemudian siapa yang berwenang untuk melaksanakan penerapan sanksi administratif. Dalam kondisi seperti ini, Pemerintah Kota Ambon agar dapat segera mengeluarkan Peraturan Walikota yang acuannya bisa diambil dari Peraturan Gubernur 5 Tahun 2020. Kemudian tujuan dan manfaat dari PSBB harus dipublikasikan, sehingga secara demokrasi ada jaminan kepada masyarakat dan masyarakat tidak ragu dengan pemerintah.

Terkaitpelaksanaan protokol kesehatan, Pemerintah Kota Ambon menetapkan beberapa aturan yang digunakan sebagai dasar hukum dalam pencegahan dan penyebaran corona virus disiase di lingkup kota Ambon, yaitu Bidang pembatasan pergerakan kendaraan orang dan barang pada awal covid, pembatasan Kegiatan Masyarakat, PSBB Tahap I dan Tahap II, PSBB transisi Tahap I sampai X beserta tugas dan fungsi bidang Pembatasan Kendaraan dan Moda Transportasi di Kota Ambon, dapat dilihat pada table berikut ini :

Tabel 1:

Tahapan PSBB, Dasar Hukum, Tugas dan Fungsi Pelaksanaan Pencegahan dan Penyebaran Covid 19

\begin{tabular}{|c|c|c|c|}
\hline No & Tahapan & Dasar Hukum & Tugas Pokok dan Fungsi \\
\hline \multirow{6}{*}{1} & \multirow{6}{*}{ Awal Covid } & Surat Edaran Walikota Ambon & \multirow{6}{*}{$\begin{array}{l}\text { - Melakukan Pengawasan serta } \\
\text { penindakan } \\
\text { dikembalikan ke tempat asal } \\
\text { bagi awak kendaraan dan } \\
\text { penumpang yang tidak } \\
\text { mematuhi protocol kesehatan } \\
\text { pada pintu-pintu masuk ke kota } \\
\text { Ambon bersama dengan instansi } \\
\text { terkait }\end{array}$} \\
\hline & & Nomor $\quad 551.1 / 05 / \mathrm{SE} / 2020$ & \\
\hline & & tentang Pencegahan dan & \\
\hline & & Disiase 2019 di Lingkup & \\
\hline & & Transportasi Angkuta Kota dan & \\
\hline & & $\begin{array}{l}\text { Angkutan Penyeberangan di } \\
\text { Teluk Ambon. }\end{array}$ & \\
\hline
\end{tabular}




\begin{tabular}{|c|c|c|c|}
\hline 2 & $\begin{array}{l}\text { Pembatasan } \\
\text { Kegiatan } \\
\text { Masyarakat }\end{array}$ & $\begin{array}{l}\text { Peraturan Walikota Ambon } \\
\text { Nomor } 16 \text { Tahun } 2020 \text { Tentang } \\
\text { Pembatasan Kegiatan Orang, } \\
\text { Aktivitas Usaha dan Moda } \\
\text { Transportasi di Kota Ambon }\end{array}$ & $\begin{array}{l}\text { - Membatasi jumlah penumpang } \\
\text { bagi kendaraan sebesar } 50 \% \text { dari } \\
\text { kapasistas muat penumpang } \\
\text { (orang) } \\
\text { - Menindak awak kendaraan dan } \\
\text { penumpang yang tidak menataati } \\
\text { protokol kesehatan }\end{array}$ \\
\hline 3 & $\begin{array}{l}\text { Pembatasan } \\
\text { Sosial Berskala } \\
\text { Besar Tahap I }\end{array}$ & $\begin{array}{l}\text { Peraturan Walikota Ambon } \\
\text { Nomor } 18 \text { tahun } 2020 \text { Tentang } \\
\text { Pelaksanaan Pembatasan Sosial } \\
\text { Berskala Besar Dalam Rangka } \\
\text { Penanganan Corona Virus } \\
\text { Disiase } 2019 \text { (COVID-19) Di } \\
\text { Kota Ambon }\end{array}$ & $\begin{array}{l}\text { - Membatasi jumlah penumpang } \\
\text { bagi kendaraan sebesar } 50 \% \text { dari } \\
\text { kapasistas muat penumpang } \\
\text { (orang) } \\
\text { - Menggunakan jadwal operasi } \\
\text { kendaraan angkutan kota } \\
\text { (menggunakan shift) } \\
\text { - Menindak awak kendaraan dan } \\
\text { penumpang yang tidak menataati } \\
\text { protokol kesehatan, kapasitas } \\
\text { muat dan jadwal operasi } \\
\text { kendaraan bagi angkot dan juga } \\
\text { AKDP }\end{array}$ \\
\hline 4 & $\begin{array}{l}\text { Pembatasan } \\
\text { Sosial Berskala } \\
\text { Besar Tahap II }\end{array}$ & $\begin{array}{l}\text { Peraturan Walikota Ambon } \\
\text { Nomor 19 tahun } 2020 \text { Tentang } \\
\text { Perubahan Atas Peraturan } \\
\text { Walikota Ambon Nomor } 18 \\
\text { tahun } 2020 \quad \text { Tentang } \\
\text { Pelaksanaan Pembatasan Sosial } \\
\text { Berskala Besar Dalam Rangka } \\
\text { Penanganan Corona Virus } \\
\text { Disiase 2019 (COVID-19) Di } \\
\text { Kota Ambon }\end{array}$ & $\begin{array}{l}\text { - Membatasi jumlah penumpang } \\
\text { bagi kendaraan sebesar } 50 \% \text { dari } \\
\text { kapasistas muat penumpang } \\
\text { (orang) } \\
\text { - Menggunakan jadwal operasi } \\
\text { kendaraan angkutan kota } \\
\text { (menggunakan shift) } \\
\text { - Membatasi jam operasional } \\
\text { angkutan kota sampai dengan } \\
\text { jam } 18.00 \\
\text { - Menindak awak kendaraan dan } \\
\text { penumpang yang tidak menataati } \\
\text { protocol kesehatan, kapasitas } \\
\text { muat dan jadwal operasi } \\
\text { kendaraan bagi angkot dan juga } \\
\text { AKDP }\end{array}$ \\
\hline 5 & $\begin{array}{l}\text { Pembatasan } \\
\text { Sosial Berskala } \\
\text { Besar Transisi } \\
\text { Tahap I - III }\end{array}$ & $\begin{array}{l}\text { Peraturan Walikota Ambon } \\
\text { Nomor } 20 \text { tahun } 2020 \text { Tentang } \\
\text { Pelaksanaan Pembatasan Sosial } \\
\text { Berskala Besar Pada Masa } \\
\text { Transisi Menuju Masyarakat } \\
\text { Sehat, Aman dan Produktif Di } \\
\text { Kota Ambon }\end{array}$ & $\begin{array}{l}\text { - Membatasi jumlah penumpang } \\
\text { bagi kendaraan sebesar } 50 \% \text { dari } \\
\text { kapasistas muat penumpang } \\
\text { (orang) } \\
\text { - Menggunakan jadwal operasi } \\
\text { kendaraan angkutan kota } \\
\text { (menggunakan shift) } \\
\text { - Membatasi jam operasional } \\
\text { angkutan kota sampai dengan } \\
\text { jam } 18.00 \\
\text { - Menindak awak kendaraan dan } \\
\text { penumpang yang tidak menataati } \\
\text { protocol kesehatan, kapasitas } \\
\text { muat dan jadwal operasi } \\
\text { kendaraan bagi angkot dan juga } \\
\text { AKDP, untuk jam operasional }\end{array}$ \\
\hline
\end{tabular}




\begin{tabular}{|c|c|c|c|}
\hline & & & $\begin{array}{lccc}\text { 6maka terminal } & \text { dan } & \text { pasar } \\
\text { d7itutup jam } & 18.00 & \text { Wit } \\
\text { (p8enyekatan) } & & \\
\end{array}$ \\
\hline 6 & $\begin{array}{l}\text { Pembatasan } \\
\text { Sosial Berskala } \\
\text { Besar Trans } \\
\text { Tahap IV - VII }\end{array}$ & $\begin{array}{l}\text { Peraturan Walikota Ambon } \\
\text { Nomor } 20 \text { tahun } 2020 \text { Tentang } \\
\text { Pelaksanaan Pembatasan Sosial } \\
\text { Berskala Besar Pada Masa } \\
\text { Transisi Menuju Masyarakat } \\
\text { Sehat, Aman dan Produktif Di } \\
\text { Kota Ambon }\end{array}$ & $\begin{array}{l}\text { - Membatasi jumlah penumpang } \\
\text { bagi kendaraan sebesar } 50 \% \text { dari } \\
\text { kapasistas muat penumpang } \\
\text { (orang) } \\
\text { - Menggunakan jadwal operasi } \\
\text { kendaraan angkutan kota } \\
\text { (menggunakan shift) } \\
\text { - Membatasi jam operasional } \\
\text { angkutan kota sampai dengan } \\
\text { jam } 18.00 \text { - Menindak awak kendaraan dan } \\
\text { penumpang yang tidak menataati } \\
\text { protocol kesehatan, kapasitas } \\
\text { muat dan jadwal operasi } \\
\text { kendaraan bagi angkot dan juga } \\
\text { AKDP, untuk jam operasional } \\
\text { maka terminal dan pasar ditutup } \\
\text { jam } 18.00 \text { Wit (penyekatan) }\end{array}$ \\
\hline 7 & $\begin{array}{l}\text { Pembatasan } \\
\text { Sosial Berskala } \\
\text { Besar Trans } \\
\text { Tahap IV - VII }\end{array}$ & $\begin{array}{l}\text { Peraturan Walikota Ambon } \\
\text { Nomor } 25 \text { tahun } 2020 \text { Tentang } \\
\text { Perubahan Atas Peraturan } \\
\text { Walikota No. } 20 \text { Tahun } 2020 \\
\text { Tentang } \\
\text { Pembatasan Sosial Berskala } \\
\text { Besar Pada Masa Transisi } \\
\text { Menuju Masyarakat Sehat, } \\
\text { Aman dan Produktif Di Kota } \\
\text { Ambon }\end{array}$ & $\begin{array}{l}\text { - Membatasi jumlah penumpang } \\
\text { bagi kendaraan sebesar } 50 \% \text { dari } \\
\text { kapasistas muat penumpang } \\
\text { (orang) } \\
\text { - Menggunakan jadwal operasi } \\
\text { kendaraan angkutan kota } \\
\text { (menggunakan shift) } \\
\text { - Membatasi jam operasional } \\
\text { angkutan kota sampai dengan } \\
\text { jam } 18.00 \text { - Menindak awak kendaraan dan } \\
\text { penumpang yang tidak menataati } \\
\text { protocol kesehatan, kapasitas } \\
\text { muat dan jadwal operasi } \\
\text { kendaraan bagi angkot dan juga } \\
\text { AKDP, untuk jam operasional } \\
\text { maka terminal dan pasar ditutup } \\
\text { jam } 18.00 \text { Wit (penyekatan) }\end{array}$ \\
\hline 8 & $\begin{array}{l}\text { Pembatasan } \\
\text { Sosial Berskala } \\
\text { Besar Trans } \\
\text { Tahap VIII-X }\end{array}$ & $\begin{array}{l}\text { Peraturan Walikota Ambon } \\
\text { Nomor } 36 \text { tahun } 2020 \text { Tentang } \\
\text { Perubahan Atas Peraturan } \\
\text { Walikota No. 25 Tahun 2020 } \\
\text { Tentang } \\
\text { Pembatasan Sosial Berskala } \\
\text { Besar Pada Masa Transisi } \\
\text { Menuju Masyarakat Sehat, } \\
\text { Aman dan Produktif Di Kota } \\
\text { Ambon }\end{array}$ & $\begin{array}{l}\text { - Membatasi jumlah penumpang } \\
\text { bagi kendaraan sebesar } 50 \% \text { dari } \\
\text { kapasistas muat penumpang } \\
\text { (orang) } \\
\text { - Menggunakan jadwal operasi } \\
\text { kendaraan angkutan kota } \\
\text { (menggunakan shift) } \\
\text { - Membatasi jam operasional } \\
\text { angkutan kota sampai dengan } \\
\text { jam } 18.00 \text { - Menindak awak kendaraan dan } \\
\text { penumpang yang tidak menataati } \\
\text { protocol kesehatan, kapasitas }\end{array}$ \\
\hline
\end{tabular}


muat dan jadwal operasi kendaraan bagi angkot dan juga AKDP, untuk jam operasional maka terminal dan pasar ditutup jam 18.00 Wit (penyekatan)

Sumber Data : Gugus Tugas Percepatan Penaganan Covid 19 Kota Ambon.

Apabila dilihat dari awal Covid, pelaksanaan PSBB Tahap I dan Tahap II, PSBB Taransisi Tahap I sampai Tahap IX sampai pada tahapan dipersidangan berdasarkan dasar hukum yang diatur dalam Peraturan Walikota dan sesuai tugas dan fungsinya yaitu Melakukan Pengawasan serta penindakan berupa dikembalikan ke tempat asal bagi awak kendaraan dan penumpang yang tidak mematuhi protokol kesehatan pada pintu-pintu masuk ke kota Ambon bersama dengan instansi terkait, Membatasi jumlah penumpang bagi kendaraan sebesar $50 \%$ dari kapasistas muat penumpang (orang), Menggunakan jadwal operasi kendaraan angkutan kota (menggunakan shift), Membatasi jam operasional angkutan kota sampai dengan jam 18.00, Menindak awak kendaraan dan penumpang yang tidak menataati protocol kesehatan, kapasitas muat dan jadwal operasi kendaraan bagi angkot dan juga AKDP, untuk jam operasional maka terminal dan pasar ditutup jam 18.00 Wit (penyekatan).

Menurut J. Slarmanat, Kepala Bagian Hukum Sekretariat Daerah Kota Ambon, Pemerintah Kota (Pemkot) Ambon memperketat penerapan Instruksi Presiden (Inpres) Nomor 6 Tahun 2020 tentang Peningkatan Disiplin dan Penegakan Hukum Protokol Kesehatan dalam Pencegahan dan Pengendalian COVID-19 sebagai bentuk tindakan nyata dalam penegakan hukum terhadap pelanggaran protokol kesehatan di kota Ambon melalui PSBB.

Diharpakan Pembatasan Sosial Berskala Besar (PSBB) transisi tahap IV akan dilaksanakan 31 Agustus -13 September 2020. PSBB transisi tahap III akan berakhir 30 Agustus 2020, selajutnya tahap IV akan memperketat penerapan Inpres Nomor 6 Tahun 2020 di seluruh segmen. Protokol kesehatan yang harus dipatuhi meliputi penggunaan masker yang menutup hidung dan mulut hingga dagu jika harus keluar rumah atau interaksi dengan orang lain yang tidak diketahui status kesehatannya, membersihkan tangan secara teratur, pembatasan interaksi fisik (physical distancing), dan meningkatkan daya tahan tubuh dengan menerapkan Perilaku Hidup Bersih dan Sehat (PHBS). Pengawasan bukan hanya diperketat di pintu masuk pelabuhan atau bandara, tapi diseluruh segmen terutama terkait penggunaan masker bagi masyarakat," katanya. Inpres yang diteken Presiden Jokowi pada 4 Agustus 2020 itu mengatur soal sanksi bagi pelanggar protokol kesehatan.

Sanksi sebagaimana dimaksud berupa, teguran lisan atau tertulis, kerja sosial, denda administratif, penghentian atau penutupan sementara penyelenggaraan usaha. Sosialisasi dan teguran penggunaan masker sesuai Inpres nomor 6 tahun 2020, ditindaklanjuti dengan dasar hukum penegakan disiplin Peraturan Gubernur nomor 42 dan Peraturan Wali Kota nomor 25 tahun 2020.Kurun waktu tiga hari kedepan, seluruh petugas terkait akan melakukan sosialisasi penerapan Inpres nomor 6 tahun 2020, yang difokuskan di pasar, cafe dan restoran juga perkantoran. Sosialisasi di pasar akan dilakukan Disperindag bersama TNI yang juga akan melakukan bakti sosial. Sementara petugas Dishub dan satpol PP dalam pengawasan keliling akan memantau titik perbatasan, serta kendaraan yang mengangkut penumpang lebih dari 50 persen kapasitas. Penegakan sanski dilakukan dengan pendekatan tindak pidana ringan, setelah melakukan koordinasi dengan pihak Kejaksaan dan Pengadilan.

\section{Penerapan Sanksi Terhadap Pelanggaran Protokol Kesehatan Pada Masa Pandemi Di Kota Ambon}

Semenjak virus Corona mewabah di sejumlah negara, kata Corona atau Covid-19 kian sering terdengar di telinga masyarakat. Sejauh ini Corona atau Covid-19 masih menjadi 
perbincangan di sejumlah negara lantaran kasusnya yang kian meningkat hingga World Health Organization (WHO) menetapkan virus tersebut menjadi pandemi. Covid-19 merupakan wabah penyakit menular yang sedang melanda berbagai negara tidak terkecuali Negara Indonesia, penularan wabah dari kota hingga desa tidak terlepas dari sasaran untuk penularannya, covid19 sendiri pertama kali muncul di Wuhan, China pada tanggal 31 Desember 2019 yang mana wabah tersebut merambah dengan cepat ke berbagai negara tidak terkecuali negara Indonesia. Wabah ini sudah banyak merenggut nyawa manusia di berbagai negara, orang yang terpapar virus tersebut akan mengalami beberapa gejala diantaraya suhu tubuh diatas 38 derajat celcius, demam, hingga sesak nafas. Lansia menjadi sasaran empuk bagi covid-19, karena imunitas tubuh yang sudah tidak kuat ${ }^{16}$.

Pemerintah Indonesia sendiri telah menetapkan virus corona sebagai jenis penyakit yang menimbulkan kedaruratan kesehatan masyarakat. Oleh karena itu, dalam rangka menghambat penyebaran virus corona, Pemerintah mengambil langkah dengan menetapkan pandemi virus corona sebagai bencana nasional dan mengimbau masyarakat untuk melakukan physical distancing serta belajar/bekerja dari rumah (work from home) ${ }^{17}$.

Ajakan yang sering disampaikan oleh pimpinan negara untuk bersatu atau Bersama melawan Covid-19 juga dapat dibaca sebagai pesan moral kebangsaan yang sangat agung, yang menunjukkan, bahwa tidak ada hal mustahil yang tidak bisa diatasi atau diselesaikan jika dilakukan dengan mengutamakan semangat dan aksi bersama atau bersatu dalam kebinekaan untuk memproteksi hak kebinekaan, khususnya dalam menghadapi serangan Covid-19 ${ }^{18}$.

Penerapan kebijakan pencegahan dan pengendalian Covid-19 merupakan proses mewujudkan kesadaran tentang kedisplinan dan penegakan hukum protokol kesehatan yang tidak mudah untuk dipatuhi. Perilaku tidak normal ditunjukkan oleh masyarakat Indonesia. Di tengah pandemi covid 19 di Indonesia yang semakin banyak menunjukkan kasus positif, masyarakat seakan tidak takut dan memilih untuk berlibur, jalan-jalan ke pusat perbelanjaan, mengadakan tabligh akbar, dan kegiatan lain yang dilakukan secara berkerumun. Hal ini tentunya bertolak belakang dengan himbauan pemerintah untuk melakukan social distancing dan tetap dirumah ${ }^{19}$.

Setiap daerah memiliki aturan sendiri untuk bisa menerapkan dan mendisiplinkan warganya di masa pandemi Covid-19 ini. Seperti halnya di Ambon, Pemerintah Kota (Pemkot) Ambon menyiapkan sejumlah sanksi administratif bagi pelanggar aturan pembatasan sosial berskala besar. Sanksi akan diberlakukan bagi pelanggar PSBB. Kita akan ketat dalam pembatasan ini mengingat tahap awal telah dimulai Pembatasan Kegiatan Masyarakat (PKM) yang dilakukan selama 14 hari. Denda diberlakukan bagi pelanggar seperti tidak menggunakan masker Rp50.000, hingga denda bagi pelaku usaha yang tidak mengikuti aturan PSBB. Pemberian sanksi akan dilakukan Penyidik Pegawai Negeri Sipil (PPNS) Pemkot Ambon didampingi aparat TNI dan Polri. Penerapan sanksi akan dikawal PPNS bersama TNI Polri. Pemerintah berharap penerapan sanksi dapat membatasi aktifitas masyarakat sesuai tahapan pembatasan.

16 Riyadi, R. R. Akibat Hukum Terjadinya Wabah Covid-19 dengan Di Berlakukannya Pasal 28 Angka 8 Undang-Undang Nomor 2 Tahun 2020 Terkait Pengalokasian Anggaran Dana Desa. Dinamika: Jurnal Ilmiah Ilmu Hukum, 27(2), 206-219.

17 Randi, Y. (2020). Pandemi Corona Sebagai Alasan Pemutusan Hubungan Kerja Pekerja Oleh Perusahaan Dikaitkan Dengan Undang-Undang Ketenagakerjaan. Yurispruden Jurnal Fakultas Hukum Universitas Islam Malang, 3(2). DOI: http://dx.doi.org/10.33474/yur.v3i2.6709.

18 Wahid, A., Sunardi, S., \& Kurniawati, D. A. (2020). Masifikasi Pendidikan Konstitusi Sebagai Proteksi Hak Kebinekaan Di Era Pandemi Covid-19. Yurispruden: Jurnal Fakultas Hukum Universitas Islam Malang, 3(2), 150-161. DOI: http://dx.doi.org/10.33474/yur.v3i2.6737.

19 Harirah, Z., \& Rizaldi, A. (2020). Merespon Nalar Kebijakan Negara Dalam Menangani Pandemi Covid 19 Di Indonesia. Jurnal Ekonomi dan Kebijakan Publik Indonesia, 7(1). DOI: https://doi.org/10.24815/ekapi.v7i1.17370. 
Di beberapa daerah kini banyak diterapkan sanksi bagi warga yang melanggar disiplin protokol kesehatan. Bentuk sanksinya pun beragam dari hal yang ringan hingga berujung denda pun diberlakukan. Namun, tidak jarang juga beberapa daerah sengaja memajang peti mati di pinggir jalan untuk mengingatkan banyak orang tentang dampak dari bahayanya penularan Covid-19. Pada dasarnya, Pemerintah telah dan selalu menghimbau seluruh masyarakat Indonesia untuk tetap disiplin dalam menjaga kesehatan dan menjalankan pola hidup yang sehat. Pemerintah juga mengingatkan agar masyarakat tetap melakukan physical distancing dan mengikuti berbagai protokol kesehatan demi mencegah penularan Virus Covid-19 ini. Pemerintah Pusat melalui Gugus Tugas Percepatan Penanganan COVID-19 membuat empat strategi untuk menguatkan kebijakan physical distancing sebagai strategi dasar demi mengatasi pandemi Virus Corona COVID-19 salah satunya penggunaan masker. Masyarakat diwajibkan menggunakan masker saat berada di ruang publik atau di luar rumah. Diharapkan agar dengan memakai masker mata rantai penularan COVID-19 mampu dicegah dan perkembangannya dapat diminimalisir dan bahkan dimusnahkan.

Apapun bentuk peraturan pemerintah daerah, seperti Peraturan Wali (Perwal) Kota Ambon Nomor 21 tahun 2020 tentang Pengunaan Masker, pada dasarnya merupkan hal yang sangat urgen. Penegakan hukum dari aspek denda administrasi bagi siapa saja yang tidak menggunakan masker di muka umum sejatinya merupakan hal yang perlu didukung oleh masyarakat kota Ambon untuk bersama-sama dan secara aktif terlibat dalam memerangi wabah Covid-19 ini. Walaupun Pemerintah kota Ambon telah melakukan edukasi dan sosialisasi tentang Covid-19, mengubah perilaku individu dari masyarakat ternyata tidaklah mudah. Banyak warga yang masih mengacuhkan peringatan Pemerintah. Di banyak tempat, penerapan New Normal justru difahami dan dijalankan oleh banyak warga dengan cara normal seperti layaknya seperti sebelum dilanda Virus Covid-19. Padahal, sebagai warga negara Indonesia yang baik, adalah wajib hukumnya mematuhi aturan Pemerintahan yang ada untuk kebaikan masayrakat itu sendiri. Apalagi kini wabah Covid-19 sedang menunjukkan taringnya. Karenanya, seluruh masyarakat Indonesia diharapkan berperan aktif menjalani segala anjuran dan aturan terkait pencegahan dan penanggulangan Covid-19 sedini mungkin.

Pelaksanaan PSBB yang dilakukan Pemerintah Kota Ambon pada Tahap I dimulai pada tanggal 22 Juni 220 sampai dengan 5 Juli 2020, PSBB Tahap II tanggal 6 Juli 2020 sampai tanggal 19 Juli 2020, PSBB Transisi Tahap I dimulai tanggal 20 Juli 2020 sampai 3 Agustus 2020. PSBB Transisi Tahap II dimulai tanggal 4 Agustus sampai 16 Agustus 2020. PSBB Transisi Tahap III dimulai tanggal 17 Agustus 2020 sampai tanggal 31 Agustus 2020. PSBB Transisi Tahap IV dimulai tanggal 1 September 2020 sampai 12 September 2020. PSBB Transisi Tahap V dimulai tanggal 13 September 2020 sampai 26 September 2020. PSBB Transisi Tahap VI dimulai tanggal 27 September 2020 sampai 11 Oktober 2020. PSBB Transisi Tahap VII dimulai tanggal 12 Oktober 2020 sampai 25 Oktober 2020. PSBB Transisi Tahap VII dimulai tanggal 26 Oktober 2020 sampai 8 November 2020. PSBB Transisi Tahap VIII dimulai tanggal 9 November 2020 sampai 23 November 2020. PSBB Transisi Tahap IX tanggal 24 November 2020.

Terdapat 3 (tiga) jenis pelanggaran protokol kesehatan yang dilakukan pelanggar pada pelaksanaan PSBB Tahap I dan Tahap II, PSBB Transisis Tahap I sampai IX dan tahapan persidangan meliputi pelanggar masker, pelanggaran jam operasional dan pelanggaran Moda transportasi yang dapat dilihat pada tabel berikut ini : 
Tabel 2.

Data Pelanggaran PSBB Tahap I s/d Transisi Tahap IX

\begin{tabular}{|c|c|c|c|c|}
\hline No & Data PSBB & $\begin{array}{c}\text { Jumlah Pelanggar } \\
\text { Masker }\end{array}$ & $\begin{array}{c}\text { Jumlah } \\
\text { Pelanggaran } \\
\text { Jam Operasional }\end{array}$ & $\begin{array}{c}\text { Jumlah } \\
\text { Pelanggaran } \\
\text { Moda } \\
\text { Transportasi } \\
\end{array}$ \\
\hline 1 & Tahap I & 24 & 32 & 30 \\
\hline 2 & Tahap II & 20 & 42 & 25 \\
\hline 3 & Transisi I & 5 & 14 & 94 \\
\hline 4 & Transisi II & 2 & 15 & 34 \\
\hline 5 & Transisi III & 0 & 0 & 0 \\
\hline 6 & Transisi IV & 3 & 1 & 37 \\
\hline 7 & Transisi V & 139 & 8 & 101 \\
\hline 8 & Transisi VI & 58 & 8 & 112 \\
\hline 9 & Transisi VII & 13 & 5 & 82 \\
\hline 10 & Transisi VIII & 16 & 0 & 37 \\
\hline 11 & Transisi IX & 38 & 2 & 94 \\
\hline 12 & Transisi X & 39 & 1 & 67 \\
\hline 13 & $\begin{array}{l}\text { Sidang Pengadilan } 18 \\
\text { September } 2020\end{array}$ & 10 & 9 & 30 \\
\hline 13 & $\begin{array}{l}\text { Sidang Pengadilan } 25 \\
\text { September } 2020\end{array}$ & 89 & 4 & 84 \\
\hline 14 & $\begin{array}{l}\text { Sidang Pengadilan } 16 \\
\text { Oktober } 2020\end{array}$ & 50 & 8 & 80 \\
\hline 15 & $\begin{array}{l}\text { Sidang Pengadilan } 13 \\
\text { November } 2020\end{array}$ & 28 & 1 & 65 \\
\hline & Jumlah & 534 & 148 & 967 \\
\hline
\end{tabular}

Sumber Data : Gugus Tugas Percepatan Penaganan Covid 19 Kota Ambon

Data pelanggaran PSBB Tahap I sampai dengan Transisi Tahap IX untuk pelanggar masker, pelanggaran jam operasional dan pelanggaran moda transportasi tiap tahapan dan transisi maupun tahapan persidangan mengalami perubahan ada yang meningkat dan ada yang menurun pelanggaran protokol kesehatan yang dilakukan oleh masyarakat, dalam pelaksanaannya mulai dari awal covid, pembatasan kegiatan masyarakat tahap I dan tahap II, tahap transisi I sampai dengan IX sampai tahapan persidangan dalam penerapan sanksinya sesuai dengan jenis pelanggaran yang dilakukan masyarakat.

Penerapan sanksi yang dikenakan kepada pelanggar protokol kesehatan berdasarkan Perwali No 20 tahun 2020 yaitu teguran tertulis, sanksi administrasi

Bentuk tindakan tegas yaitu, dengan membuat surat tilang kepada angkot tersebut untuk selanjutnya akan mengikuti sidang tindak pidana ringan atau Tipiring di Pengadilan Negeri (PN). Petugas yang turun langsung menindaki sejumlah pengguna lalu lintas dan warga masyarakat yang tidak patuhi protokol kesehatan baik berupa penggunaan masker mengangkut penumpang melebihi 50 persen. Dan untuk masyarakat yang tidak menggunakan masker diperintahkan push-up. Sanksi yang diberikan itu melibatkan unsur TNI/Polri, dan aparatur sipil negara (ASN) untuk melaksanakan operasi justisia sebagai bentuk implementasi Inpres nomor 6 tahun 2020 tentang peningkatan disiplin dan penegakan hukum protokol kesehatan dalam pencegahan dan pengendalian Covid-19.

Penegakan Hukum Terhadap pelanggaran protokol kesehatan pada masa pandemi covid 19 di kota Ambon dilaksanakan berdasarkan peraturan perundang-undangan, dengan

$$
\text { 241|S A S Vol. } 27 \text { No.2, April - Juni } 2021
$$


melakukan Pembatasan Kegiatan Masyarakat (PKM), Pembatasan Sosial Berskala Besar (PSBB) sebagai bentuk penegakan hukum terhadap pelanggaran protokol kesehatan pada masa pandemi covid 19 di Kota Ambon melalui sosialisasi-sosialisasi dalam pencegahan penyebaran virus covid 19 dan Pembatasan Sosial Berskala Besar (PSBB) dengan menerapkan sanksi terhadap pelanggar. Namun penegakan hukum terhadap pelanggaran protokol kesehatan belum terlaksana dengan baik. Hal ini disebabkan masih terjadinya pelanggaran-pelanggaran protokol kesehatan yang dilakukan oleh masyarakat di kota Ambon.

Pada masa pandemi covid-19 pemerintah Kota Ambon telah melakukan melakukan penegakan hukum pelanggaran kesehatan melalui upaya prenventif dan upaya represif Yang dilakukan instansi-instansi yang tergabung dalam gugus tugas pananganan covid-19 Kota Ambon yaitu Dinas Perhubungan dan Satuan Polisi Pamong Praja dibantu dengan TNi dan Kepolisian.

Upaya yang dilakukan Pemerintah Kota Ambon melalui upaya preventif dan upaya represif. Upaya preventif dengan melakukan sosialisasi kepada seluruh lapisan masyarakat agar pentingnya menjaga dan melaksanakan protokol kesehatan di saat-saat suasana kehidupan masyarakat tidak kondusif dan tampak tidak menentu akibat wabah Covid-19 dengan segala akibat buruknya seperti kesehatan, ekonomi, sosial, dan juga pendidikan.

Upaya represif yang dilakukan oleh Pemerintah Kota Ambon untuk menegakan protokol kesehatan ditengah tingginya angka terkonfirmasi positif covid-19 dengan menggiring para pelanggar protokol ke pengadilan, dengan adanya penindakan itu maka terlihat pemerintah Kota Ambon sudah mulai menegakan protokol kesehatan sebagaimana yang atur dalam Inpres 6 Tahun 2020 tentang penegakan protokol kesehatan.

Penegakan Hukum Terhadap pelanggaran protokol kesehatan pada masa pandemi covid 19 di kota Ambon dilaksanakan berdasarkan peraturan perundang-undangan, dengan melakukan Pembatasan Kegiatan Masyarakat (PKM), Pembatasan Sosial Berskala Besar (PSBB) sebagai bentuk penegakan hukum terhadap pelanggaran protokol kesehatan pada masa pandemi covid 19 di Kota Ambon melalui sosialisasi-sosialisasi dalam pencegahan penyebaran virus covid 19 dan Pembatasan Sosial Berskala Besar (PSBB) dengan menerapkan sanksi terhadap pelanggar. Namun penegakan hukum terhadap pelanggaran protokol kesehatan belum terlaksana dengan baik. Hal ini disebabkan masih terjadinya pelanggaran-pelanggaran protokol kesehatan yang dilakukan oleh masyarakat di kota Ambon.

Dari sekian sanksi yang telah dicantumkan dalam masing-masing kebijakan memiliki tujuan agar pelanggar merasakan efek jera dari perbuatannya tersebut. Secara umum, sanksi dalam peraturan peraturan perundang-undangan, termasuk juga sanksi administratif, biasanya dikaitkan denganatau sebagai konsekuensi dari suatu norma yang dirumuskan dalam bentuk larangan, perintah (keharusan), atau wajib (kewajiban). Suatu norma yang berisi larangan, perintah (keharusan), atau wajib (kewajiban) pada umumnya akan mengalami kesulitan dalam penegakannya apabila tidak disertai dengan sanksi ${ }^{20}$.

Di beberapa daerah kini banyak diterapkan sanksi bagi warga yang melanggar disiplin protokol kesehatan. Bentuk sanksinya pun beragam dari hal yang ringan hingga berujung denda pun diberlakukan. Namun, tidak jarang juga beberapa daerah sengaja memajang peti mati di pinggir jalan untuk mengingatkan banyak orang tentang dampak dari bahayanya penularan Covid-19.

Pengawasan bukan hanya diperketat di pintu masuk pelabuhan atau bandara, tapi diseluruh segmen terutama terkait penggunaan masker bagi masyarakat. Inpres yang diteken Presiden Jokowi pada 4 Agustus 2020 itu mengatur soal sanksi bagi pelanggar protokol

20 Setiadi, W. (2018). Sanksi Administratif sebagai salah satu instrumen penegakan hukum dalam peraturan perundang-undangan. Jurnal Legislasi Indonesia, 6(4), 603-614. jurnal.peraturan.go.id/index.php/jli/article/view/336. 
kesehatan. Sanksi sebagaimana dimaksud berupa, teguran lisan atau tertulis, kerja sosial, denda administratif, penghentian atau penutupan sementara penyelenggaraan usaha. Richard menjelaskan, sosialisasi dan teguran penggunaan masker sesuai Inpres nomor 6 tahun 2020, ditindaklanjuti dengan dasar hukum penegakan disiplin Peraturan Gubernur nomor 42 dan Peraturan Wali Kota nomor 25 tahun 2020. Kurun waktu tiga hari kedepan, seluruh petugas terkait akan melakukan sosialisasi penerapan Inpres nomor 6 tahun 2020, yang difokuskan di pasar, cafe dan restoran juga perkantoran. Sosialisasi di pasar akan dilakukan Disperindag bersama TNI yang juga akan melakukan bakti sosial.

Sementara petugas Dishub dan satpol PP dalam pengawasan keliling akan memantau titik perbatasan, serta kendaraan yang mengangkut penumpang lebih dari 50 persen kapasitas, penegakan sanski dilakukan dengan pendekatan tindak pidana ringan, setelah melakukan koordinasi dengan pihak Kejaksaan dan Pengadilan ${ }^{21}$.

Pemerintah Kota (Pemkot) Ambon, Maluku akan memberikan sanksi tegas kepada pelanggaar di hari ketiga pemberlakuan Pembatasan Sosial Berskala Besar (PSBB). Sanksi tersebut berupa teguran lisan, tertulis, administrasi, sosial hingga denda. Wali Kota Ambon, Richard Louhenapessy mengatakan, sanksi tegas akan diberikan kepada para pelanggar tanpa kecuali. Sanksi tersebut diatur dalam Peraturan Wali Kota Ambon (Perwali) Nomor 18 tahun 2020 tentang PSBB.

Sementara denda administratif berlaku untuk setiap tahapan PSBB, yakni dimulai Rp50.000 hingga Rp30 juta bagi pelanggar. Bagi pelanggar seperti tidak menggunakan masker misalnya yakni Rp50.000. Pemberian sanksi akan dilakukan Penyidik Pegawai Negeri Sipil (PPNS) Pemkot Ambon didampingi aparat TNI dan Polri.

Di beberapa daerah kini banyak diterapkan sanksi bagi warga yang melanggar disiplin protokol kesehatan. Bentuk sanksinya pun beragam dari hal yang ringan hingga berujung denda pun diberlakukan. Namun, tidak jarang juga beberapa daerah sengaja memajang peti mati di pinggir jalan untuk mengingatkan banyak orang tentang dampak dari bahayanya penularan Covid-19. Pada dasarnya, Pemerintah telah dan selalu menghimbau seluruh masyarakat Indonesia untuk tetap disiplin dalam menjaga kesehatan dan menjalankan pola hidup yang sehat. Pemerintah juga mengingatkan agar masyarakat tetap melakukan physical distancing dan mengikuti berbagai protokol kesehatan demi mencegah penularan Virus Covid-19 ini.

Pemerintah Pusat melalui Gugus Tugas Percepatan Penanganan COVID-19 membuat empat strategi untuk menguatkan kebijakan physical distancing sebagai strategi dasar demi mengatasi pandemi Virus Corona COVID-19 salah satunya penggunaan masker. Masyarakat diwajibkan menggunakan masker saat berada di ruang publik atau di luar rumah. Diharapkan agar dengan memakai masker mata rantai penularan COVID-19 mampu dicegah dan perkembangannya dapat diminimalisir dan bahkan dimusnahkan.

Apapun bentuk peraturan pemerintah daerah, seperti Peraturan Wali (Perwali) Kota Ambon Nomor 21 tahun 2020 tentang Pelaksanaan Pembatasan Sosial Berskala Besar Dalam Penanganan Corono Virus Disease 19, pada dasarnya merupkan hal yang sangat urgen. Penegakan hukum dari aspek denda administrasi bagi siapa saja yang tidak menggunakan masker di muka umum sejatinya merupakan hal yang perlu didukung oleh masyarakat kota Ambon untuk bersama-sama dan secara aktif terlibat dalam memerangi wabah Covid-19 ini. Walaupun Pemerintah kota Ambon telah melakukan edukasi dan sosialisasi tentang Covid-19, mengubah perilaku individu dari masyarakat ternyata tidaklah mudah. Banyak warga yang masih mengacuhkan peringatan Pemerintah.

21 Antara Maluku, Pemerintah Kota Ambon Memperketat Penarapan Inpres No. 6 tahun 2020. https://ambon.antaranews.com/berita/85738/pemkot-ambon-perketat-penerapan-inpres-no-6-tahun-2020, (Diakses 15 November 2020).

$$
\text { 243|S A S I Vol. } 27 \text { No.2, April - Juni } 2021
$$


Terkait dengan hal tersebut, dibutuhkan penegakan hukum dalam menerapkan sanksi nagi pelanggar protokol kesehatan. Pemerintah Kota (Pemkot) Ambon, Maluku akan memberikan sanksi tegas kepada pelanggaar dalam pemberlakuan Pembatasan Sosial Berskala Besar (PSBB). Sanksi tersebut berupa teguran lisan, tertulis, administrasi, sosial hingga denda. Penerapan sanksi tegas akan diberikan kepada para pelanggar tanpa kecuali. Sanksi tersebut diatur dalam Peraturan Wali Kota Ambon (Perwali) Nomor 18 tahun 2020 tentang PSBB. Penerapan sanksi tegas berupa sanksi administrasi, sosial hingga denda tanpa kecuali. Sementara denda administratif berlaku untuk setiap tahapan PSBB, yakni dimulai Rp50.000 hingga Rp30 juta bagi pelanggar. Bagi pelanggar seperti tidak menggunakan masker misalnya yakni Rp50.000.

Pemberian sanksi yang tegas yang dilakukan Penyidik Pegawai Negeri Sipil (PPNS) Pemkot Ambon didampingi aparat TNI dan Polri bagi pelanggar protokol kesehatan berupa penggunaan masker, jam operasional dan jasa moda transportasi khususnya di Kota Ambon agar masyarakat sadar akan pentingnya menjaga kesehatan dan memutus mata rantai peneybaran virus. Namun ketegasan di sini juga perlu dibarengi dengan kebijaksanaan dari Pemerintah Kota Ambon agar apa yang diamanatkan dalam peraturan perundang-undangan dapat dilaksanakan.

Penerapan sanksi terhadap pelanggaran protokol kesehatan pada masa pandemi covid 19 di kota Ambon yang diatur dalam Peraturan Wali Kota Ambon tentang PSBB dengan menerapkan sanksi teguran tertulis, sanksi administrasi, sanksi sosial dan sanksi pidana kepada pelanggar. Namun penerapan sanksi terhadap pelanggar belum memberikan efek jera kepada pelanggar protokol kesehatan.

Berdasarkan hasil wawancara dengan Robby Sapulete selaku Kepala Dinas Perhubungan terkait dengan pelaksanaan penegakan hukum protokol kesehatan sudah dilaksanakan sesuai dengan aturan yang berlaku dan kerjasama antara instansi dapat berjalan dengan baik dan pemerintah Kota Ambon melalui gugus tugas melakukan operasi yustisi dengan melibatkan instansi Satuan Pamong Praja, Dinas perhubungan bekerjasama dengan TNI dan Kepolisian.

Penerapan Pembatasan Sosial Berskala Besar (PSBB) di Kota Ambon fokus pada operasi yustisi. Operasi disertai pemberian sanksi bagi mereka yang melanggar protokol kesehatan. Kebijakan ini diambil dalam rangka memutuskan mata rantai penyebaran Covid-19 di Kota Ambon. Operasi yustisi disiplin protokol kesehatan digelar Pemkot Ambon melibatkan TNIPolri. Operasi yustisi merupakan implementasi Inpres nomor 6 tahun 2020, sehingga masyarakat patuh pada protokol kesehatan yakni menggunakan masker, mencuci tangan, menjaga jarak dan menghindari kerumunan. Hukuman yang diterapkan berupa sanksi sosial. Di antaranya membersihkan lingkungan, menyanyikan lagu kebangsaan hingga denda administratif. Diharapkan melalui operasi yustisi ini dapat menurunkan angka kasus Covid-19, dan meningkatkan kesadaran masyarakat.

Diperlukan kerjasama antara Pemerintah Kota Ambon (Dinas Perhubungan dan Satpol PP) didampingi oleh kepolisian dan TNI serta masyarakat guna melakukan pencegahan penyebaran virus covid 19 dan memutus mata rantai penyebaran covid 19.Di banyak tempat, penerapan New Normal justru difahami dan dijalankan oleh banyak warga dengan cara normal seperti layaknya seperti sebelum dilanda Virus Covid-19. Padahal, sebagai warga negara Indonesia yang baik, adalah wajib hukumnya mematuhi aturan Pemerintahan yang ada untuk kebaikan masayrakat itu sendiri. Apalagi kini wabah Covid-19 sedang menunjukkan taringnya. Karenanya, seluruh masyarakat Indonesia diharapkan berperan aktif menjalani segala anjuran dan aturan terkait pencegahan dan penanggulangan Covid-19 sedini mungkin.

\section{P E N U T U P}

Penegakan Hukum Terhadap pelanggaran protokol kesehatan pada masa pandemi covid19 di kota Ambon dilaksanakan berdasarkan peraturan perundang-undangan, dengan 244|SASI Vo1. 27 No.2,April - Juni 2021 
melakukan Pembatasan Kegiatan Masyarakat (PKM), Pembatasan Sosial Berskala Besar (PSBB) sebagai bentuk penegakan hukum terhadap pelanggaran protokol kesehatan pada masa pandemi covid 19 di Kota Ambon melalui sosialisasi-sosialisasi dalam pencegahan penyebaran virus covid 19 dan Pembatasan Sosial Berskala Besar (PSBB) dengan menerapkan sanksi terhadap pelanggar. Namun penegakan hukum terhadap pelanggaran protokol kesehatan belum terlaksana dengan baik. Hal ini disebabkan masih terjadinya pelanggaran-pelanggaran protokol kesehatan yang dilakukan oleh masyarakat di kota Ambon.Penerapan sanksi terhadap pelanggaran protokol kesehatan pada masa pandemi covid 19 di kota Ambon yang diatur dalam Peraturan Wali Kota Ambon tentang PSBB dengan menerapkan sanksi teguran tertulis, sanksi administrasi, sanksi sosial dan sanksi pidana kepada pelanggar. Namun penerapan sanksi terhadap pelanggar belum memberikan efek jera kepada pelanggar protokol kesehatan. Adapun rekomendasi dari hasil penelitian ini antara lain, diperlukan kesadaran dan kepatuhan masyarakat untuk menaati aturan protokol kesehatan yang telah diatur dalam peraturan perundang-undangan. Penerapan sanksi tegas masih perlu dilakukan bagi pelanggar protokol kesehatan sehingga memberikan efek jera dan dapat membatasi aktivitas masyarakat agar dapat memutus mata rantai penyebaran covid-19. Selainitu, diperlukan kerjasama antara Pemerintah Kota Ambon (Dinas Perhubungan dan Satpol PP) didampingi oleh kepolisian dan TNI serta masyarakat guna melakukan pencegahan penyebaran virus covid-19 dan memutus mata rantai penyebaran covid 19 .

\section{DAFTAR PUSTAKA}

\section{Jurnal}

[1] Harirah, Z., \& Rizaldi, A. (2020). Merespon Nalar Kebijakan Negara Dalam Menangani Pandemi Covid 19 Di Indonesia. Jurnal Ekonomi dan Kebijakan Publik Indonesia, 7(1). DOI: https://doi.org/10.24815/ekapi.v7i1.17370.

[2] Juaningsih, I. N., Consuello, Y., Tarmidzi, A., \& NurIrfan, D. (2020). Optimalisasi Kebijakan Pemerintah dalam penanganan Covid-19 terhadap Masyarakat Indonesia. SALAM: Jurnal Sosial dan Budaya Syar-i,7(6), 509-518. DOI: https://doi.org/10.15408/sjsbs.v7i6.15363.

[3] Made, I. L. (2020). Signifikansi Pengaruh Sentimen Pemberlakuan PSBB Terhadap Aspek Ekonomi: Pengaruh Pada Nilai Tukar Rupiah dan Stock Return (Studi Kasus Pandemi Covid-19). Jurnal Bina Akuntansi, 7(2), 223-239. DOI: https://doi.org/10.52859/jba.v7i2.98.

[4] Masrul, M., Tasnim, J. S., Daud Oris Krianto Sulaiman, C. P., Purnomo, A., Febrianty, D. H. S., Purba, D. W., \& Ramadhani, Y. R. (2020). Pandemik COVID-19: Persoalan dan Refleksi di Indonesia. Medan: Yayasan Kita Menulis.

[5] Nasruddin, R., \& Haq, I. (2020). Pembatasan sosial berskala besar (PSBB) dan masyarakat berpenghasilan rendah. SALAM: Jurnal Sosial dan Budaya Syar-i, 7(7), 639-648. DOI: https://doi.org/10.15408/sjsbs.v7i7.15569.

[6] Randi, Y. (2020). Pandemi Corona Sebagai Alasan Pemutusan Hubungan Kerja Pekerja Oleh Perusahaan Dikaitkan Dengan Undang-Undang Ketenagakerjaan. Yurispruden Jurnal Fakultas Hukum Universitas Islam Malang, 3(2). DOI: http://dx.doi.org/10.33474/yur.v3i2.6709.

[7] Riyadi, R. R. Akibat Hukum Terjadinya Wabah Covid-19 dengan Di Berlakukannya Pasal 28 Angka 8 Undang-Undang Nomor 2 Tahun 2020 Terkait Pengalokasian Anggaran Dana Desa. Dinamika: Jurnal Ilmiah Ilmu Hukum, 27(2), 206-219.

[8] Saragih, N. I., Hartati, V., \& Fauzi, M. (2020). Tren, Tantangan, dan Perspektif dalam Sistem Logistik pada Masa dan Pasca (New Normal) Pandemik Covid-19 di Indonesia. Jurnal Rekayasa Sistem Industri,9(2), 77-86. DOI: 
https://doi.org/10.26593/jrsi.v9i2.4009.77-86.

[9] Setiadi, W. (2018). Sanksi Administratif sebagai salah satu instrumen penegakan hukum dalam peraturan perundang-undangan. Jurnal Legislasi Indonesia, 6(4), 603-614. https://ejurnal.peraturan.go.id/index.php/jli/article/view/336.

[10] Wahid, A., Sunardi, S., \& Kurniawati, D. A. (2020). Masifikasi Pendidikan Konstitusi Sebagai Proteksi Hak Kebinekaan Di Era Pandemi Covid-19. Yurispruden: Jurnal Fakultas Hukum Universitas Islam Malang, 3(2), 150-161. DOI: http://dx.doi.org/10.33474/yur.v3i2.6737.

[11]Zahrotunnimah, Z. (2020). Langkah taktis pemerintah daerah dalam pencegahan penyebaran virus Corona Covid-19 di Indonesia. SALAM: Jurnal Sosial Dan Budaya SyarI, 7(3), 247-260. DOI: https://doi.org/10.15408/sjsbs.v7i3.15103.

\section{Buku}

[12] Apeldoorn, L. V., \& Van, L. J. (2009). Pengantar Ilmu Hukum, terjemahan Oetarid Sadino. Jakarta: Pradnya Paramitha.

[13] Arief, B. N. (1997). Beberapa aspek kebijakan penegakan dan pengembangan hukum pidana. Bandung: Citra Aditya Bakti.

[14]Fuady, M. (2007). Sosiologi Hukum Kontemporer, Interaksi Kekeuasaan, Hukum, dan Masyarakat, Bandung: Citra Aditya Bakti.

[15] Sunarso, S. (2005). Wawasan Penegakan Hukum di Indonesia. Bandung: Citra Aditya Bakti.

\section{Online/World Wide Web}

[16] Antara Maluku, Pemerintah Kota Ambon Memperketat Penarapan Inpres No. 6 tahun 2020. https://ambon.antaranews.com/berita/85738/pemkot-ambon-perketat-penerapan-inpresno-6-tahun-2020.

[17]Berita Satu Suara Pembaharuan, Tajuk Rencana, Penegakan Protokol Kesehatan, https://beritasatumedia.cld.bz/SP-200718/6/.

[18] Siregar, S. N. Polisi Di Masa Pandemi Covid-19:Kompleksitas Masalah Penegakan Hukum dan Pilihan Solusi, Pusat Penelitian Politik, http://www.politik.lipi.go.id/kolom/kolom2/politik-nasional/1391-polri-di-masa-pandemi-covid-19-kompleksitas-masalahpenegakan-hukum-dan-pilihan-solusi.

[19] Very, Protokol Kesehatan Dibuat untuk Kesehatan dan Keselamatan Masyarakat dari Wabah Covid-19, Indonews.id, https://indonews.id/artikel/29311/Protokol-KesehatanDibuat-untuk-Kesehatan-dan-Keselamatan-Masyarakat-dari-Wabah-Covid-19/. 